This is an electronic version of an article accepted for publication in New Review of Academic Librarianship, 24(4). It was published online on February 18, 2016, and is available at: http://www.tandfonline.com/doi/full/10.1080/13614533.2016.1138135.

\title{
Factors Underlying Technology Adoption in Academic Libraries in Kuwait
}

\author{
MESHAL AL-FADHLI \\ Department of Library \& Information Science, College of Basic Education. \\ Public Authority for Applied Education \& Training, Adeliya, Kuwait \\ SHEILA CORRALL \\ School of Information Sciences, University of Pittsburgh, Pittsburgh, USA \\ ANDREW COX \\ Information School, University of Sheffield, Sheffield, UK
}

\begin{abstract}
The study analysed factors shaping adoption of technology in academic libraries in Kuwait. The research was based on interviews conducted with library directors, staff and users, combined with observation and document analysis. A major aspect of the Kuwaiti context was a relative lack of financial restraints and an enthusiasm for technology within society as a whole. Other important influences shaping technology adoption specifically within libraries were the top down decision making style and a quest for prestige, in a context of a lack of library culture among users, shortage of professional staff and a strong, perhaps exaggerated, faith in technology as a solution to problems.
\end{abstract}

KEYWORDS: developing countries, management styles, national culture, professional status, technology adoption

\section{INTRODUCTION}

Globally adoption of technology has been a key aspect of change in academic libraries in the last few decades. Reflecting this, there is much LIS literature about new technologies. A majority of such literature deals with one particular new technology, often being a case study of the implementation process written by the library staff involved themselves. Such case studies, based on a single institution's experience, authored by interested parties, tend to focus on technology features and issues, and although also describing participative processes of adoption, are inherently somewhat descriptive. Such work is professionally useful because it tells us about issues for those thinking also of adopting the same technology (though published results may under-represent the problems encountered). Other studies are sector surveys to measure the extent of new technology adoption. Yet there is a relative shortage of studies that seek to understand underlying factors that shape technology adoption in academic libraries in one country as a whole, over time.

In addition, of course, the majority of the existing literature is based on the experience of developed countries, typically the first to adopt any particular new technology. There are 
many exceptions of studies in developing countries, where often lack of funds and basic infrastructure are underlying conditions shaping adoption. Yet in some developing countries where these basic infrastructures do exist, as in the Arabian Gulf, there are other important socio-technical challenges that may be more important aspects of modernisation that need to be explored to understand technology adoption.

Thus there is little literature on technology adoption in academic libraries in Gulf countries like Kuwait. What does exist primarily seeks to establish a basic picture across the country of technologies in use. This paper seeks to move beyond such descriptive groundwork. The aim of this study was to explore the character of technology adoption in the academic libraries in Kuwait, with a stress on identifying underlying factors that condition adoption in the sector, rather than focus on immediate outcomes and choices. The scope was core collection-related systems, both the Integrated Library System, including self-service and e-collections, and security systems, including RFID.

The paper is laid out as follows. It begins by exploring what we know about the Kuwaiti academic library sector and also the broader context. Then the method of the study is introduced. The findings are set out in the next section. The discussion section reviews what we have learned about the factors shaping technology adoption. The conclusion summarises the contribution, considers the implications for practice and suggests areas for future research.

\section{TECHNOLOGY USE IN ACADEMIC LIBRARIES IN KUWAIT}

Kuwait is a small country with a fairly new university sector, so one would not expect a very large body of previous literature on academic libraries in the country. Indeed a number of scholars have acknowledged that the technological situation of libraries in the Gulf as a whole is under-researched (Boumarafi, 1996; Qari, 1998; Al-Qallaf \& Al-Azmi, 2002). Anwar and Al-Ansari (2002) and Rehman and Al-Ansari (2003) argue that the underlying reason is that faculty members of librarianship departments in the Gulf region are not very productive in their publications in the English language and very little of their output has been accepted in well regarded LIS journals. The authors consider the literature in the Arabic language also weak and poorly researched. Nevertheless, there have been a few useful studies of the academic library sector as a whole that can provide a useful context to the current study.

For example, Al-Keranej (2005) found that there is a lack of awareness among most lecturers, faculty members, and university managers about the role and usage of the academic library. Al-Keranej's (2005) findings echo the earlier conclusion of Zehery (1975, p. 13) that

Kuwait libraries in general suffer tremendously ... from an identity crisis and recognition ... of the vital role of the library as a dynamic social institution.

Zehery (1997) himself repeated a similar message two decades later in reporting the results of a study of the Gulf as a whole. This later study recognised that progress had been made, but still identified a number of important obstacles to library use, the most important of which were that:

- Most university libraries play no role in the development of the academic programmes.

- All courses are developed in a way that depends heavily on course textbooks.

- Lecturers select and assign textbooks every year. Students can acquire the books from the university for a minimal price. 
- Lecturers often do not require students to read additional material beyond the assigned books.

- Most students visit the library to study from their assigned books.

- In general, students lack training in the use of bibliographic tools, reference resources, and research techniques required to develop a good research paper.

Al-Muomen, Morris and Maynard (2012) are rather more optimistic about lecturers' understanding of the importance of the library, though confirm a lack of collaboration between them and librarians.

As regards technology in academic libraries in Kuwait as such, research is still in its infancy, reflecting also the relative recency of the emergence of an academic system. AlQallaf (2006) found that librarians are optimistic about technology and believe that it improves performance of their tasks. However, she also found that staff had a sense of lack of recognition and felt ICT training and support in general were poor. This led to a level of "technostress". An early study by Qari (1998) also suggested that there is an absence of professional LIS graduate staff that can deal with electronic services and a lack of training programmes to keep staff up to date with the current development of ICT.

Khurshid (2003) surveyed the library management system (LMS) marketplace across the whole Gulf region. More recently, Marimuthu and Paraman (2011) provide a useful descriptive overview of technologies specifically in use across the Kuwaiti academic library sector. In a relevant more in-depth study, Rehman and Al-Huraiti (2010) surveyed the factors affecting the progress of LMS in six Kuwaiti Higher Education (HE) institutions. One of the significant findings of the study was that the University of Kuwait had not fully utilized the circulation model provided in Horizon. In the context of a lack of financial obstacles, Rehman and Al-Huraiti (2010, p. 870) suggest the need for a study to investigate "factors that might have delayed this crucial application". One factor is the lack of local representation of the system suppliers (Khurshid and Al-Baridi, 2010).

Thus we know a little about the relevant background to academic libraries in Kuwait. A picture is also emerging from survey work of the overall pattern of technology adoption. Yet we lack more in-depth case studies of the technology adoption process in Kuwaiti academic libraries, and the Gulf more generally. In particular, there is a lack of qualitative case study material that explores the context of technology adoption in its widest sense. This paper is intended to make a contribution to filling that gap by exploring in-depth slowchanging underlying cultural factors shaping the use of technology in Kuwaiti academic libraries. First, it is useful to sketch in a broader picture of the character of Kuwait as a state.

\section{CONTEXT}

The state of Kuwait is a small country of about 18 square kilometres and a population of around four million, and situated on the Arabian Gulf (CIA factbook, 2015). One third of the population is Kuwaiti nationals; the rest are migrants from other Arab countries and Asia. The constitution established after independence (1962) embodied the right to state Education for all Kuwaiti citizens (Ministry of Education, 2008). The first university was founded by the Government four years later and a second established in the 1980s. More recently a number of private universities have been established.

To establish the wider context of the study, it is helpful to have some awareness of the character of the Kuwaiti economy and the Government focus on technology for development (see Table 1). The economy of Kuwait does not fit easily into the traditional global economic classification of being either a developed or developing economy, but rather it falls 
somewhere in between the two. Several indicators suggest that Kuwait has the character of a developed economy, such as high per capita income, a high savings rate, a strong annual growth rate and a consistently healthy balance of payments (Casey, 2007; Russell, 2008). On the other hand, it also has the features of a developing economy, such as dependence on a single-product oil economy; lack of human resources with professional skills and knowledge of modern management techniques (Al-Ali, 1991; Dollman, 2007; Porter, Ketels \& Delgado, 2008); a small national labour force (Al-Ali, 1991; Al-Athari \& Zairi, 2002) and a heavy dependence on the importation of capital and consumer commodities.

TABLE 1: Profile of the State of Kuwait

\begin{tabular}{lcl}
\hline Dimension & Number/Percent & Source \\
\hline Population & $3,697,292$ & MADAR (2012) \\
Urban population & $98.3 \%$ & UNICEF (2014) \\
Population employed in public sector & $>80 \%$ & BTI (2014) \\
Literacy rate (2011) & $86.62 \%$ & MADAR (2012) \\
Adult literacy rate & $93.9 \%$ & UNICEF (2014) \\
Gross enrolment rate in secondary education (2003/4) & $95 \%$ & UNESCO (2011) \\
Internet users (2011) & $1,853,394$ & MADAR (2012) \\
Internet penetration (2011) & $50.13 \%$ & MADAR (2012) \\
Global rank & 64 th & MADAR (2012) \\
Arab countries rank & 3 rd & MADAR (2012) \\
Fixed broadband Internet (2011) & $181,750(4.92 \%)$ & MADAR (2012) \\
Mobile phone subscription (2011) & $4,973,160$ & MADAR (2012) \\
Mobile phone penetration (2011) & $134.51 \%$ & MADAR (2012) \\
Global rank & $32 \mathrm{nd}$ & MADAR (2012) \\
Arab countries rank & 6 th & MADAR (2012) \\
Bandwidth per user (2011) & Not available & MADAR (2012) \\
ICT Development Index global ranking (2015) & 46 th & ITU (2015) \\
Arab countries rank & 5 th & ITU (2015) \\
\hline
\end{tabular}

Since the 1990 invasion, Kuwait's first concern has been to develop ambitious strategies, policies and plans at all economic levels in order to diversify its sources of national income, rather than relying on a finite natural resource, oil (Al-Yagout, 1997; Ali \& Magalhaes, 2008). One objective has been to turn Kuwait into a regional trade centre that can compete with the other financial centres in the Middle East; Sheikh Mohamed Al-Sabah, Minister of Foreign Affairs, has declared that:

Kuwait is ideally placed to be the regional trade and financial centre, not necessarily for the Gulf, but for the whole Middle East (Hajek, 2005, p. 2).

In response to these ambitions, the Kuwaiti national assembly approved a five-year Development Plan 2009-2014 with an indicative budget of US \$125 billion (the equivalent of $£ 81.25$ billion) (Hasan \& Mohamed, 2010). Among the pillars of this policy, was the opening of doors to the participation of the private sector and Foreign Direct Investment (FDI) (Ali \& Magalhaes, 2008; Hasan \& Mohamed, 2010). The sectors in which foreign investors may invest in Kuwait were not restricted. However, investors were required to form 
a partnership with Kuwaitis and Kuwaitis must hold a majority share of the equity (AlYagout, 1997). One of the sectors where the Kuwait government opened the national market for FDI was HE. The purpose was to develop the skills of Kuwaiti youth to overcome the lack of human resource and also to open new fields for producing goods and services (Popescu, 2010). With this step, the government of Kuwait sought to establish a strong bridge in terms of relations with investors on the one hand and, on the other, to ensure high-quality education drawing from the rich experience of developed countries that incorporates the latest educational technology (Dollman, 2007; Mills, 2009).

A second pillar of the Development Plan was technology. FDI was a vehicle to gain the benefit of transmission of new technological innovations (Archibugi \& Pietrobelli, 2003; Popescu, 2010). Many countries today rely on the successful assimilation of foreign technology to achieve indigenous technological development instead of building their own technology (Taqi, 1996; Archibugi \& Pietrobelli, 2003). The continuous development of technology can originate new products and services and open the doors to new industries (Taqi, 1996; Fu, Pietrobelli \& Soete, 2011). Furthermore, a sectoral plan was laid down within the Development Plan for the field of ICT in the form of a national e-strategy (ESCWA, 2009; 2013). The plan was to build the information society in principal sectors of the state, such as education, health, trade and industry and it involved the implementation of 30 projects, 20 of these projects being in cooperation with a global leader in the field of information, Singapore (Al-Freih, 2005). Projects at the time of the research included:

- Progress towards fulfilment of national policies and strategies

- ICT infrastructure

- Access to information and knowledge

- ICT capacity building

- Building confidence and security in the use of ICTs

- Enabling environment and several others (ESCWA, 2009).

This focus in national economic policy on technology at the time the study was conducted is an essential background to approaches to technology on the ground, such as in Kuwaiti Academic libraries. While it appears that many of the planned projects were not successfully implemented, the more recent 2015-20 plan reiterates many of the same goals and undertakes to complete projects that had not been delivered within the earlier plan (Oxford Business Group, 2015).

Another indication of the focus on technology in the Kuwaiti economy is the large domestic technology market. According to Business Monitor International Research, in January 2010 Kuwait ranked as the third largest computer market among the Gulf countries, with an expectation that local ICT spending would reach around US\$761 million that year, despite the effects of the regional economic slowdown (BMI, 2010).

\section{METHODOLOGY}

At the time the study was conducted the HE sector in Kuwait consisted of:

- Kuwait University (KU), founded in 1966.

- The Public Authority for Applied Education \& Training (PAAET), founded in 1982.

- Gulf University for Science \& Technology (GUST), founded in 2002.

- Arabian Open University (AOU), founded in 2003. 
- Kuwait-Maastricht Business School (KMBS), founded in 2003.

- American University of Kuwait (AUK), founded in 2003.

- Australian College of Kuwait (ACK), founded in 2004.

Three cases studies were selected to represent these institutions in the study. Kuwait University was selected from the Government sector. PAAET would have been hard to study because of the gender segregation restricting researcher access to participants. KU as a somewhat larger institution (with $30 \mathrm{~K}$ enrolled students, compared to less than 3000 for the others) had multiple libraries. The central library, Jabeer Al-Ahmid Central Library (JACL) was chosen for the study as most comparable to the others. AOU and ACK were excluded because they lacked physical libraries. KMBS is a small college that is purely for Masters level study. This led to the selection of GUST and AUK as case studies for the research. Both have strong links to US universities.

A pilot study based on interviews with participants at the target institutions laid the ground work for the project through sharpening the study focus and gaining familiarity with the context. The main data collection was during 2008 by structured observation and document analysis, focus groups with students (one at each of the institutions, each comprising of 8 participants) and staff interviews (see Table 2). The approach to data collection was approved by ethics reviewers at the UK institution where the researchers were based. Given our focus on slow changing cultural aspects underlying decision making we believe the findings remain current and useful.

Observation was used to capture the physical environment of the library and unobtrusively observe staff-user interactions. Documents such as library policy, handbooks and guidelines were used to build up a more complete picture of the library services. Unfortunately, due to the competitive nature of the context the library strategy of only one of the institutions (AUK) was made available to the study. Statistics of usage were gained for American University of Kuwait and Kuwait University. Based on an understanding gained through this ground work, focus groups with students were undertaken. The final stage of data collection was interviews with a small but purposive sample of library staff, intended to represent the range of management levels in the organisation (see Table 2). Interviews lasted between 80 minutes and 110 minutes. They were undertaken in librarians' offices during working hours.

TABLE 2: $\quad$ Summary of Interview Participants

\begin{tabular}{lcccc}
\hline Interviews & Library Assistants & Librarians & $\begin{array}{l}\text { Heads of Departments } \\
\text { and Assistant Directors }\end{array}$ & Directors \\
\hline GUST & & 3 & & 1 \\
AUK & 3 & 3 & 1 & 1 \\
JACL & 1 & 2 & 2 & 1 \\
\hline
\end{tabular}

A thematic analysis approach was taken to analysing this corpus of data, following the guidelines of Braun and Clarke (2006). This follows the logic of familiarisation, initial coding, searching for themes, review of themes, final definition of themes, and reporting. Each case was written up, then a cross case analysis was developed synthesising themes from across all three cases. After this, the researchers consulted the wider LIS literature and other relevant literature (e.g., organisation studies, education) to attempt to confirm/disconfirm the character of the factors that were emerging from the data. 


\section{FINDINGS}

\section{Status of Technology Adoption}

All three libraries had adopted the Horizon library management system. Some online selfservice facilities were being made available, but none of the libraries had introduced selfcheckout of printed books. Indeed JACL at Kuwait University was still using a semi-manual circulation system. All offered the full range of electronic resources from ejournals to ebooks. However, the balance of the collections was different reflecting the different subjects taught in the institutions. American University of Kuwait had a focus on ejournals in English; Gulf University for Science \& Technology ebooks in English. Their physical collections were relatively small. The Kuwait University collection was largely built on printed works in Arabic, mostly because of the shortage of electronic content in Arabic in the less technical/management areas of study it supported. Acquisition decisions were made by the library director. AUK and GUST were both using RFID in their small print collections. Only GUST and AUK had federated search facilities.

The libraries were keen users of technology and library directors and staff showed great faith in the power of technology to improve services. Yet decision making appeared to be very top down, with a minimal reliance on participation of staff or users. Library staff had strong status concerns and were troubled by the lack of library culture among students, that was evident in low use of services. At the Gulf University for Science \& Technology there was a perceived lack of library use, despite the investment in technology. Students were seen as over-dependent on staff. At Kuwait University there seemed to be a level of mutual distrust between students and staff; a problem that also seemed to exist at the American University of Kuwait. So while there was a strong orientation to technology, the libraries seemed to continue to have many problems in implementing it in successful services. The following sections explore what the study found to be the main underlying factors behind this dilemma.

\section{Economic Position and Government Policy}

It can be argued that the economic situation of Kuwait and related government policy have played a vital role in shaping the adoption of new technologies in academic libraries in Kuwait. None of the three libraries studied had ever experienced any financial obstacles, particularly with the funding of technology adoption projects. This suggestion is supported by the literature, for instance the Dean of Admission and Registration of the American University of Kuwait is reported as stating that:

We have been fortunate in receiving approval on all requests' submitted to the budget committee for technology-related funding (Dollman, 2007, p. 62).

The relatively liberal availability of financial resources and a vibrant domestic technology market has been noted as a major factor that drives adoption of new innovations/technology (Nour, 2002), especially when combined with a technology oriented national economic policy.

Understandably, Kuwaiti Academic Libraries showed the influence of the wider focus on technology in policy and the heavy investment in technology as described in the section on context above. The link between national economic conditions and policy and library practice was clearest in the case of the Gulf University for Science \& Technology, as 
document analysis revealed. It was explicitly founded as a "University of the Future", the most technologically advanced university in the Gulf region.

The curriculum emphasizes incorporation of the latest technology into the classroom in order to enhance students' learning experience and prepare them for the global marketplace (GUST, 2009).

In adaptation to this the collection was largely in English and provided in electronic form. As a member of library staff commented:

"We have to keep pace with technological trends ... it is a high-tech university and we should have all the stuff available to our students. In fact, when it comes to the market we have it here".

Similarly at JACL at Kuwait University the library mission emphasized a commitment "to provide a high standard of information services that reflects the constantly evolving field of information technology" For confidentiality reasons the research did not have access to the library strategies of GUST and KU, but certainly for AUK their strategic plan was centred on adopting new technologies.

Thus there was a very positive environment favouring the adoption of new technologies, with a lack of financial restraint and a policy context emphasizing technology as a solution.

\section{Decision Making Style}

A second major aspect of technology adoption revolved around the style of decision making in the three libraries. The study found that library staff were not involved in decision making related to the adoption of technology. All staff interviewee participants emphasized that the director of the library was the only person who made decisions about adopting new technologies, for example one said that

" $\ldots$ The director is the only one who decides what we will introduce or adopt in the future ..."

Although the discourse of basing services on user needs was evident in talk about technologies in use, some librarians also commented on the fact that students' opinions and preferences had not been investigated prior to the planning for acquiring the new technology. For example, one stated that:

"We do not take students' opinion into account when we develop a library service. We are librarians and we are capable of taking decisions. Developing library services will be based on our evaluations, needs and ability ... We do not want students to tell us about their needs, we know them".

Lack of user consultation was partly attributable to shortages of skilled professionals who could undertake systematic evaluation.

"Some librarians are not qualified enough ... Also, there was an English language problem; the librarians couldn't read the menus and follow the steps. There was not enough experience among the librarians, neither a technological background". 
“... I do not have librarians with IT efficiencies ... I cannot be an administrator, technician and a librarian ...”.

This is consistent with the findings of Al-Qallaf (2006) who also discovered that staff in Kuwaiti libraries were not consulted about technology decisions. Yet interestingly, while in her study it was found that staff felt frustration at their lack of involvement in decision making, in the current study staff approved of this authoritarian style and saw their own role as following instructions:

"We cannot interfere or even make a suggestion for a development. This is not one of our tasks. The only person who is allowed [to be involved in the decision making related to] the development of services is the director ..."

While this management style speeded up decision making, it seemed to lead to failures to implement technology in successful ways.

These findings accord with the comments of Muna (1980) and Abdalla and AlHomoud (2001) who suggest that there is an acceptance and legitimisation of more directive and autocratic management styles in the Arab countries, particularly those in the Middle East. A number of scholars have suggested that the dominant management style in Kuwait is authoritarian (Atiyyah, 1992; Abdalla \& Al-Homoud, 2001; Welsh \& Raven, 2004). In such cultures both the managers and the subordinates accept unequal relationships. Decision making style is known to be an important factor influencing technology adoption (Sarosa \& Underwood, 2005; Al-Shohaib, Frederick, Al-Kandari \& Dorsher, 2010).

A number of models of national cultural values have been developed, but Hofstede's (1983) is the most commonly used (Jones \& Alony, 2007; de Mooii \& Hofstede, 2010). Hofstede (1983) identified four cultural dimensions to characterize different societies, later extended to five (Hofstede, 1994; Silvius, 2008) namely: Power Distance, Individualism/Collectivism, Uncertainty Avoidance, Masculinity/Feminity and Long/Short Term Orientation. Kuwait was included in one of three regions studied by Hofstede (1994), which comprised seven Arab countries from North Africa and the Middle East, including the Gulf countries. High Power Distance was identified as the predominant characteristic for the countries in this region (Hofstede, 1983; Hofstede, Hofstede \& Hofstede, 2005). Societies with a high Power Distance Index tend to accept power inequalities, and in these societies people are inclined to depend on those who hold power and authority (Rarick \& Nickerson, 2006).

We suggest that underlying this finding is the culture of "Al-qabila" (tribalism):

As Arabs were nomadic people, territory was not a major element in their social identity [...] For most Arabs, then, the tribe was their main social reference; it commanded their total loyalty and they lived and died for it (Chourou, 2005, pp. 49$50)$.

Among the main tribal values are pride in their origin, high respect for paternal authority, cohesion, patriotism and bravery. The family plays a major role in ensuring that these values are transferred to new generations. It teaches children loyalty to the Bedouin Sheikh (tribal leader). The high respect within the family accorded to paternal authority is reflected outside the family by the similar respect to the tribal leader.

Abdalla and Al-Homoud (2001, p. 524) indicate that managers, influenced by the tribal traditions, 
...often proudly boast their imported modern technology and work design, but in practice they put it to the service of socio-political expectations. They hire, motivate, organise, and direct in ways that are more consistent with their traditional tribal culture than with the modern system they have proudly introduced. They are still very proud of their tradition and they want modern systems, often for the sake of looking modern.

Thus, in addition, to the favourable economic and government policy context, decision making favoured seeing technology as a solution to many problems, but it worked in a way that was not grounded in participation of stakeholders.

\section{Kuwaiti Education and Librarians' Status}

The study also traced a link from the character of the Kuwaiti educational system to librarians' concerns with status and image, and further through to the character of technology adoption. The study showed that librarians feel that their role is not respected or understood by students and that the community as a whole did not understand their profession. For example, one participant said that

"The university is not interested in libraries and their developments".

"They [students] do not understand the concept of the library..."

Another member of the library staff said that

“... They [library users] ... think the library is only for books and a quiet environment for reading. There are lots of facilities and services we can provide ..."

Another commented:

"We probably don't respect the fact that the students might have an opinion. We think they are young and they don't know what they are doing."

Other studies of Kuwait have suggested such a lack of awareness of the library (e.g. Al Muomen et al., 2012). This is also consistent with studies in many other countries which have identified such misperceptions among library users about librarians and libraries, and particularly a lack of awareness of librarians' role, duties and skills (Bickley \& Corrall, 2011; Fagan, 2003; Gardner \& Eng, 2005; Majid \& Haidar, 2008). Actually such damaging misconceptions are not unique to librarianship. Public misperceptions are a general problem causing dissatisfaction and severe negative feelings in a number professions, such as medicine, business and law (Khani, Jaafarpour \& Dyrekvandmogadam, 2008; Lerner, 2006; Monk-Turner, O'Leary \& Sumter, 2010; Whysall, Foster \& Harris, 2009). Studies have suggested a link between public perception and job satisfaction. For example, Wotruba (1990) studied the relationship of job image, performance and job satisfaction of salesmen, and found that salespeople with more negative perceptions of their job were also dissatisfied with their job. Thus such concerns could be linked to the low job satisfaction felt by some librarians in the libraries in the study.

In the case of librarianship in Kuwait there was a direct link between lack of understanding and low status of librarians to the nature of the educational system. The Kuwaiti educational system tends to be instructivist, teacher directed, in its approach and downplays the need for students to actively search for material for themselves. A member of library staff commented: 
“... lecturers are not $[\ldots]$ giving assignments that direct students to visit and to use the library".

One student commented:

"The professors facilitate the study process by giving us one paper and telling us to learn all the content in this paper by heart, in order to write it in the exam ..."

Students learned through lectures and lecturer preferred texts. In some of the focus groups students admitted to little awareness of library services:

"To be frank, I just found out after I had been studying in the university for more than one year that I can borrow books. What I had in mind was that books were placed on the shelves just to give an implication that this is a library".

Prior school education similarly neglected libraries. One of the staff interviewees suggested that:

"They [students] have not received a proper education that makes them use the library ... this is mainly because of the ... education system. Students do not learn the approach of doing research; they only receive information but they never search for it.”

More specifically this focus on instructivism was linked to a lack of information literacy (IL) skills, which was itself a factor in the public's negative image of libraries and librarians. This is consistent with the findings of Rehman and Alfaresi (2009), who found that a majority of Kuwait female high school students were deficient in their information literacy, lacking skills in:

- Catalogue searching and use

- Selection of information resources

- Formulation of search strategies; and

- Selection of pertinent resources.

Similarly university students in this study also seemed to lack IL skills. Students either did not use the library or wanted lots of help. This lack of library culture was linked to a lack of a sense of responsibility and discipline, at least in the opinion of staff. In general the study discovered a mix of unhelpful relationships between students and staff. At the American University of Kuwait, for example students preferred to deal with student employees rather than professional staff. This seemed to be tied to the tensions arising from the low perceived status of the profession. Staff saw students as over-dependent and demanding. Some comments at the Gulf University for Science \& Technology suggested the same culture there. This was likely to reinforce the way that decisions about technology adoption failed to involve direct consultation to discover user needs and was seen as a reason not to adopt some technologies, e.g. self-service book issue.

Kuwaiti academic librarians expressed the need to challenge the image of the library and promote their profession in a number of ways. However, in the case of the libraries investigated in this study, the misperception of the library and the librarians' image described above was also identified as a cause directing Kuwaiti academic librarians to further adopt new technologies. The drive behind this technology adoption was to improve the library 
image and to introduce new job titles that had a level of status that staff were satisfied with. For example, one of the library staff interviewees stated that

"We have to keep pace with technological trends ..."

“... [our profession] will be changed to 'information specialist', not as a librarian anymore. We are providing information, controlling and managing the library ..."

This was not a uni-directional or simple driver. Some technologies were resisted because a completely virtual library might lead to loss of a role for librarians. In other staff interviews it was also apparent that the shortage of staff drives technology adoption.

\section{"Technolust" in the Librarianship Profession}

The continuous adoption of technologies in the last few decades has affected every aspect of the library (Wood \& Walther, 2000). Yet Mallery (2008), for example, highlights a number of areas of technological failure. The author criticizes approaches undertaken by librarians who do not follow systematic methods when adopting technologies in libraries and argues that: "technology is not the best solution for every problem in the library" (Mallery, 2008, p. 23). Indeed, some researchers in librarianship have identified a tendency for librarians to be over enthusiastic about adopting technology, using such terms as technolust, technocratism, technojunkies and technophilia (Crawford \& Gorman, 1995; Stephens, 2004). Crawford and Gorman (1995, p. 36) define technolust by stating that it

is characterized by an excessive fascination with the newest toys and an unreasoning faith in the new.

Similarly, Stephens (2004, p. 36) defines technolust as

An irrational love for new technology combined with unrealistic expectations for the solutions it brings.

Thus in the view of some commentators the increasing introduction of technology/ICT services in libraries has often been based on false expectations and unrealistic decisions (Green, 1994; Crawford \& Gorman, 1995). For instance, Green (1994) claims that overgenerous promises of what librarians can offer to their users can be a barrier to change, as it is associated with false and unrealised expectations attached to the introduction of technology/ICT.

Kuwaiti academic library decision makers' high expectations of technology/ICT and the level of optimism associated with technology, as revealed by the study findings, were apparent in the interviews. This kind of optimism was reflected in quotes such as:

"For sure it [technology] will give advantages. Because that will make the process very easy for librarians and users and the service will be more accepted and faster for the user".

Another staff interviewee stated:

"[The technologies we have] appeared gradually. Meaning, we have the plan that everything new that emerges in the market, we get it. So, we try to be updated with every new thing ... We make a study, but not an expensive study ... We take a decision between us as librarians and we see what the new things are". 
This excessive expectation of technology/ICT is evidence of the way many organisational problems were handled by Kuwaiti academic library decision makers, by opting for technology solutions without studying the context systematically and contemplating the different solutions available. For instance, to deal with the problem of shortage of staff, a librarian interviewee said that

“... We are looking forward for more self-service and we are moving with this trend, however we want to adopt the self-service technologies to overcome the problem of the shortage of staff ..."

This is not to say that there were no cases where Kuwaiti academic libraries did not adopt the latest technology. RFID was seen as too costly at Kuwait University. Important barriers to adopting new technologies were lack of IT support and the lack of suppliers' presence in the region (Khurshid \& Al-Baridi, 2010). But there was a sense overall that in many cases Kuwaiti academic librarians tended to adopt new technologies just for the sake of keeping pace with the latest trends, rather than based on a reasoned evaluation of its usefulness. This is evident in statements by librarians such as:

"We have to keep pace with technological trends ... it is a high-tech university ... In fact; when it comes to the market we have it here".

Other librarians commented:

"... We follow the latest technological trends and it is a must, this is because we have to be at the same line with other libraries".

"... I mean I follow the latest in the field ... what is available in the international market ... In fact, when it comes to the market we have it here".

Thus the adoption of technology was driven by sectoral fashion, rather than user-focused evaluation.

The tendency to see technology as a solution could be linked back to wider societal trends in which government economic policy is centred on technology investment. In this context, a professional tendency to technolust was reinforced.

\section{DISCUSSION}

The study identified some of the main underlying factors shaping the character of adoption of technology in three academic libraries in Kuwait. A major aspect of the context was a relative lack of financial restraints and the focus on technology within Kuwaiti economy/society as a whole. The Kuwaiti economy was buoyant, and one of the main focuses of government policy was on modernisation through technology. Government policy filtered down to institutional level policies and thence to library strategy, leading to a privileging of technology based initiatives. None of the libraries had ever experienced a rejection of a technological plan, based on financial reasons. There was probably a link also between this wider context and individual staff attitudes of faith, even over confidence, in the benefits of technology.

Another major influence on technology adoption was the top down pattern of decision making. A strong common characteristic of the three institutions was that decisions about technology (and other matters, such as acquisitions) were made by the director with relatively 
little consultation with staff or user requirements gathering. Thus decision making was rapid, but technology adoption was not a participative process or based on systematic investigation of user need. Staff seemed to accept this approach to management. This feature of the situation could be said to be also linked to the lack of staff, because the library directors lacked staff with technical knowledge to engage in more sophisticated forms of technology evaluation. But at a deeper level such an approach to authority was also tied to the tribal traditions of Kuwaiti society.

Another significant factor was that it appeared that staff attitudes towards technology, including those of the library directors, were related to a quest for prestige. Being a librarian or being called a librarian was held in low esteem. Thus library directors and their staff were interested in new job titles, such as "Information Specialist" that implied to them a more technical role, and used language explicitly connecting the profession to references to access to information and knowledge in the national e-strategy (ESCWA, 2009). In a society generally excited by technology this is not surprising. Yet it was also linked to the fundamental character of the Education system where an instructivist logic meant that libraries are seen as of low importance. The style of teaching in all three institutions was instructivist, i.e. learning was through lectures based on the lecturer's/instructor's choice of a few text books. There was generally no expectation of further reading. The school system similarly downplayed the role of libraries. Thus students had low information literacy skills. This partly explained the low status of the library and a disconnect from academic staff and students. The instructivist pedagogy, or "sage on the stage" model (King, 1993, p. 30) could again be tentatively linked to general attitudes to authority. Acceptance of the lecturer as directing learning could be seen as another example of the deferential attitude to authority in Kuwaiti culture as a whole.

Another important factor shaping the adoption of technology was the shortage of trained professional staff. All three libraries complained about staff workload and insufficient numbers of staff. Difficulty recruiting staff could itself potentially have been partly an outcome of the low status of the profession. All the libraries saw technology as a means to address the staff shortage. Yet staffing was also a technology adoption constraint. Because of the lack of librarians with expertise in ICT, unsystematic approaches were taken to adopting technology. It thus reinforced the concentration of decision making in the hands of the library director. It could also be linked to the strength of the perceived need to have local support services from suppliers prior to adoption of new technologies. Despite the focus in national policy on technology there were still crucial gaps in terms of local technological support (Khurshid \& Al-Baridi, 2010).

A final factor shaping the adoption of technology was that library staff showed a strong, arguably exaggerated, faith in technology as a solution to problems: technolust. This could be linked to the general climate of the country where modernity is linked to technology in government policy and also evident in a very strong market for technology gadgets in the country as a whole.

\section{CONCLUSIONS}

While other studies have established a descriptive characterisation of the adoption of technologies in academic libraries in Kuwait (e.g. Marimuthu \& Paraman, 2011) this paper sought to develop a deeper understanding of factors underlying their adoption and use. It identified factors in the areas of national policy, decision making styles, library/librarian status, staff shortages and "technolust". Several of these were both drivers and inhibitors, and the factors also bear a rather complex relation to each other. Taken together they seem to 
explain the strong orientation to technology solutions found in the libraries, but with problems of actual implementation and take-up.

At a practical level on the basis of this analysis, no easy recommendations can be made to move forward. A tangle of issues around the nature of the curriculum, a lack of library culture among students, the status of libraries and librarians, and problematic relationships between students and library staff call for a range of actions. Training library staff to improve their technology skills would facilitate the distribution of decision making and help give it a firmer base in systematic requirements gathering. Training around communicating with users more effectively would also be productive. In this context the country's wealth, technology focus in policy and positive attitudes towards technology (even an element of "technolust") could be harnessed in positive directions.

At the policy level, shifting away from an excessive focus on technology and greater investment in staff skills would be positive. The recruitment of staff with strong technical skills to work in libraries is important, as is a move towards more inclusive and participative decision making processes. This demands new styles of leadership from library directors. Longer term initiatives at the level of the Education ministry to enrich the curriculum and move away from instructivism when combined with moves to improve students' understanding of the value of libraries would constitute positive interventions.

Further research is needed to extend and update the findings within Kuwait's academic libraries. The Kuwaiti HEI sector has seen a further expansion since this study was conducted: What is the pattern across the sector as a whole? Many of the generic factors may also apply beyond the university sector. More work is also needed to extend the study to the rest of the Gulf states, where it is recognised that broadly the same underlying factors, with some variation, are at work. This would give us a much deeper understanding of how technologies are adopted and used in the region.

\section{REFERENCES}

Abdalla, I. A., \& Al-Homoud, M. A. (2001). Exploring the implicit leadership theory in the Arabian Gulf States. Applied Psychology an International Review, 50(4), 506-531. doi:10.1111/1464-0597.00071.

Al-Ali, S. (1991). Technological dependence in developing countries: A case study of Kuwait. Technology in Society, 13(3), 267-277.

Al-Athari, A., \& Zairi, M. (2002). Training evaluation: An empirical study in Kuwait. Journal of European Industrial Training, 26(5), 241-251. doi:10.1108/03090590210424911.

Al-Freih, F. (2005). Minister of Communications, Sheikh Ahmed Al-Abdalla, at the inauguration of the Technology Support Center. e.Kuwait, 1(5), 1.

Al-Keranej, N. M. (2005). التربية كلية مكتبات خدمات من المستفيدين احتياجات تحديد Determining the needs of the users of the College of Basic Education Libraries services, resources and potentials in the State of Kuwait]. ال 25(3), 139-180.

Al-Muomen, N., Morris, A., \& Maynard, S. (2012). Modelling information-seeking behaviour of graduate students at Kuwait university. Journal of Documentation, 68(4), 430-459. doi:10.1108/00220411211239057.

Al-Qallaf, C. L. (2006). Librarians and technology in academic and research libraries in Kuwait: Perceptions and effects. Libri, 56(3), 168-179. doi:10.1515/LIBR.2006.168.

Al-Qallaf, C. L., \& Al-Azmi, H. M. (2002). Information technology in public libraries in Kuwait: A first study. International Information and Library Review, 34(4), 289-308. doi:10.1006/iilr.2002. 
Al-Shohaib, K., Frederick, E., Al-Kandari, A. A. J., \& Dorsher, M. D. (2010). Factors influencing the adoption of the internet by public relations professionals in the private and public sectors of Saudi Arabia. Management Communication Quarterly, 24(1), 104-121. doi:10.1177/0893318909351433.

Al-Yagout, M. M. A. (1997). The regulation of foreign investment in Kuwait: The role of law, politics and economic policy in the development process. $\mathrm{PhD}$ thesis, University of Warwick.

Ali, G. E., \& Magalhaes, R. (2008). Barriers to implementing e-learning: A Kuwaiti case study. International Journal of Training and Development, 12(1), 36-53. doi:10.1111/j.1468-2419.2007.00294.x.

Anwar, M. A., \& Al-Ansari, H. (2002). Developing working LIS professionals in the Gulf Cooperation Council countries: A study of the perceptions of deans and directors of academic libraries. The Electronic Library, 20(3), 231-240. doi: $10.1108 / 02640470210432384$.

Archibugi, D., \& Pietrobelli, C. (2003). The globalization of technology and its implications for developing countries: Windows of opportunity or further burden? Technological Forecasting \& Social Change, 70(9), 861-883.

Atiyyah, H. S. (1992). Research note: Research in Arab countries, published in Arabic. Organization Studies, 13(1), 105-110. doi:10.1177/017084069201300108.

Bickley, R., \& Corrall, S. (2011). Student perceptions of staff in the Information Commons: A study at the University of Sheffield. Reference Services Review, 29(2), 223-243. doi:10.1108/00907321111135466.

BMI (2010). Kuwait information technology report Q1 2010. London: Business Monitor International.

Boumarafi, B. M. (1996). Libraries and information services in the United Arab Emirates (UAE): An overview. International Information and Library Review, 28(4), 331-343. doi:10.1006/iilr.1996.0022.

Braun, V., \& Clarke, V. (2006). Using thematic analysis in psychology. Qualitative Research in Psychology, 3(2), 77-101. doi:10.1191/1478088706qp063oa.

BTI (2014). Kuwait Country Report. Gütersloh, Germany: Bertelsmann Stiftung. Retrieved November 22, 2015, from http://www.btiproject.org/uploads/tx_itao_download/BTI_2014_Kuwait.pdf.

Casey, M. S. (2007). The history of Kuwait. Westport, CT: Greenwood Press.

Chourou, B. (2005). Promoting human security: Ethical, normative and educational frameworks in the Arab States. Paris, France: UNESCO. Retrieved October 30, 2015, from http://unesdoc.unesco.org/images/0014/001405/140513E.pdf.

CIA (2015). The world factbook: Kuwait. Washington, D.C.: Central Intelligence Agency. Retrieved October 30, 2015, from https://www.cia.gov/library/publications/the-worldfactbook/geos/ku.html.

Crawford, W., \& Gorman, M. (1995). Future libraries: Dreams, madness \& reality. Chicago: American Library Association.

de Mooij, M., \& Hofstede, G. (2010). The Hofstede model: Applications to global branding and advertising strategy and research. International Journal of Advertising, 29(1), 85110. doi:10.2501/S026504870920104X.

Dollman, S. (2007). A model of American higher education in the Middle East. EDUCAUSE Quarterly, 30(3), 59-62. Retrieved October 30, 2015, from https://net.educause.edu/ir/library/pdf/EQM07310.pdf.

ESCWA (2009). National profile of the information society in Kuwait. New York: United Nations, Economic and Social Commission for Western Asia. Retrieved October 30, 2015, from http://www.escwa.un.org/wsis/reports/docs/Kuwait-09-e.pdf. 
ESCWA (2013). National profile of the information society in Kuwait. New York: United Nations, Economic and Social Commission for Western Asia. Retrieved November 22, 2015, from http://www.escwa.un.org/wsis/reports/docs/Kuwait-2013-En.pdf.

Fagan, J. (2003). Students' perceptions of academic librarians. The Reference Librarian, 37(78), 131-148. doi:10.1300/J120v37n78.

$\mathrm{Fu}, \mathrm{X}$., Pietrobelli, C., \& Soete, L. (2011). The role of foreign technology and indigenous innovation in the emerging economies: Technological change and catching-up. World Development, 39(7), 1204-1212. doi:10.1016/j.worlddev.2010.05.009

Gardner, S., \& Eng, S. (2005). What students want: Generation Y and the changing function of the academic library. portal: Libraries and the Academy, 5(3), 405-420. doi:10.1353/pla.2005.0034.

Green, T. (1994). Images and perceptions as barriers to the use of library staff and services. New Library World, 95(7), 19-24. doi:10.1108/03074809410070520.

GUST (2009). Admission and registration manual 2008-2009. Kuwait City, Kuwait: Gulf University for Science and Technology.

Hajek, R. (2005). Business opportunities: An investment prospective for 2005. International Press Services (IPS).

Hasan, F. \& Mohamed, W. S. (2010). Kuwait approves US\$125bn Development Plan. Kuwait City, Kuwait: Global Investment House. Retrieved October 30, 2015, from http://www.globalinv.net/research/kuwait-development-012010.pdf.

Hofstede, G. (1983). National cultures in four dimensions: A research-based theory of cultural differences among nations. International Studies of Management \& Organization, 13(1/2), 46-74.

Hofstede, G. (1994). Management scientists are human. Management Science, 40(1), 4-13. doi: $10.1287 / \mathrm{mnsc} .40 .1 .4$.

Hofstede, G., Hofstede, G.H. \& Hofstede, G.J. (2005). Cultures and organizations: Software of the mind (2nd ed.). New York: McGraw-Hill.

ITU (2015). Measuring the Information Society Report 2015. Retrieved November 22, 2015, from http://www.itu.int/en/ITU-

D/Statistics/Documents/publications/misr2015/MISR2015-w5.pdf. Geneva, Switzerland: International Telecommunication Union.

Jones, M., \& Alony, I. (2007). The cultural impact of information systems - through the eyes of Hofstede - a critical journey. Issues in Informing Science \& Information Technology, 4, 407-419.

Khani, A., Jaafarpour, M., \& Dyrekvandmogadam, A. (2008). Quality of nursing work life. Journal of Clinical and Diagnostic Research, 2(6), 1169-1174. Retrieved October 30, 2015, from http://www.jcdr.net/articles/pdf/380/307.pdf.

Khurshid, Z. (2003). A survey of the Arabian Gulf library automation marketplace. Program, 37(4), 226-233. doi:10.1108/00330330310500702.

Khurshid, Z., \& Al-Baridi, S. A. (2010). System migration from horizon to symphony at King Fahd University of Petroleum and Minerals. IFLA Journal, 36(3), 251-258. doi: $10.1177 / 0340035210378712$.

King, A. (1993). From sage on the stage to guide on the side. College Teaching, 41(1), 30-35. doi:10.1080/87567555.1993.9926781.

Lerner, G. (2006). How teaching political and ethical theory could help solve two of the legal profession's biggest problems. Georgetown Journal of Legal Ethics, 19(3), 781.

MADAR Research and Development (2012). Arab ICT use and social networks adoption report. Riyadh, Saudi Arabia: King Abdulaziz City for Science and Technology (KACST). Retrieved November 22, 2015, from http://www.kacst.edu.sa/en/about/publications/Pages/other.aspx. 
Majid, S., \& Haider, A. (2008). Image problem even haunts hi-tech libraries: Stereotypes associated with library and information professionals in Singapore. Aslib Proceedings, 60(3), 229-241. doi:10.1108/00012530810879105.

Mallery, M. (2008). Tales of technology innovation GONE WRONG. Computers in Libraries, 28(4), 22-25.

Marimuthu, V., \& Paraman, V. (2011). Analysis of information technology (IT) applications in academic libraries in Kuwait. Library Hi Tech News, 28(2), 9-15. doi:10.1108/07419051111135227.

Mills, A. (2009). New private universities in Kuwait pin their hopes on U.S. partners. The Chronicle of Higher Education, 55(37), A.24-29.

Ministry of Education. State of Kuwait. (2008). The national report: Development of Education in the State of Kuwait, 2004-2008. Geneva, Switzerland: UNESCO International Bureau of Education. Retrieved November 22, 2015, from http://www.ibe.unesco.org/National_Reports/ICE_2008/kuwait_NR08.pdf.

Monk-Turner, E., O'Leary, D., \& Sumter, M. (2010). Factors shaping police retention: Does Herzberg's theory of satisfaction hold? The Police Journal: Theory, Practice and Principles, 83(2), 164-180. doi:10.1350/pojo.2010.83.2.494.

Muna, F. (1980). The Arab executive. New York: St Martin's Press.

Nour, S. S. O. M. (2002, September). ICT opportunities and challenges for development in the Arab World. WIDER Discussion Papers/World Institute for Development Economics (UNU-WIDER), No. 2002/83. Retrieved October 30, 2015, from http://hdl.handle.net/10419/52891.

Oxford Business Group (2015). The report: Kuwait 2015. Retrieved 22 November, 2015 from http://www.oxfordbusinessgroup.com/kuwait-2015 .

Qari, A. A. (1998). Electronic library and library and information science departments in the Arabian Gulf region. Journal of Education for Library and Information Science, $39(1), 28-37$.

Popescu, R. G. (2010). The impact of foreign direct investments on labour productivity: A review of the evidence and implications. The Romanian Economic Journal, XIII(36), 137-154. Retrieved October 30, 2015, from http://www.rejournal.eu/article/risks-andconsequences-demographic-changes-romania.

Porter, M. E., Ketels, C., \& Delgado, M. (2007). The microeconomic foundations of prosperity: Findings from the business competitiveness index. In A. López-Claros, M. E. Porter, X. Sala-i-Martin \& K. Schwab (Eds.), The global competitiveness report 2007-2008 (pp. 51-81). Basingstoke, UK: Palgrave Macmillan.

Rarick, C.A. \& Nickerson, I. (2006, February 20). An exploratory study of Myanmar culture using Hofstede's value dimensions. doi:10.2139/ssrn.1114625. Retrieved from http://ssrn.com/abstract=1114625.

Rehman, S. U., \& Al-Ansari, H. (2003). The digital marketplace and library and information education in the GCC member nations: A critical review. Library Review, 52(4), 170179. doi:10.1108/00242530310470739.

Rehman, S. U., \& Al-Huraiti, R. (2010). Integrated systems applications in Kuwait academic libraries. The Electronic Library, 28(6), 858-872. doi:10.1108/02640471011093543.

Rehman, S. U., \& Alfaresi, S. (2009). Information literacy skills among female students in Kuwaiti high schools. Library Review, 58(8), 607-616. doi:10.1108/00242530910987091.

Russell, M. E. (2008). Economic and investment research: The State of Kuwait-visit report. London: City of London Investment Management Company. Retrieved October 30, 2015, from http://www.citlon.co.uk/special_reports/KuwaitVisitReport.pdf. 
Sarosa, S., \& Underwood, J. (2005). Factors affecting IT adoption within Indonesian SMEs: manager's perspectives. Proceedings of the 9th Pacific Asia Conference on Information Systems (PACIS 2005), Bangkok, Thailand (pp. 59-68). Retrieved October 30, 2015, from http://www.pacis-net.org/file/2005/150.pdf.

Silvius, A. J. G. (2008). The impact of national cultures on business \& IT alignment. Communications of the IIMA, 8(2), 11-22.

Stephens, M. (2004). Technoplans vs. technolust: A well-thought-out technology plan can help libraries stay on course. Library Journal, 129(18), 36-37.

Taqi, A. (1996). الكويت في المسح تحليل :النامية البلدان إلى الدارية المعرفة نقل transfer of management knowledge to developing countries: A survey analysis in Kuwait]. Journal of King Saud University, 8 (2), 513-536.

UNESCO (2011) World data on Education: Kuwait (7th ed.). Geneva, Switzerland: International Bureau of Education. Retrieved November 22, 2015, from http://www.ibe.unesco.org/fileadmin/user_upload/Publications/WDE/2010/pdfversions/Kuwait.pdf.

UNICEF (2015). At a glance: Kuwait. New York: UNICEF. Retrieved November, 22, 2015 from http://www.unicef.org/infobycountry/kuwait statistics.html

Welsh, D. H., \& Raven, P. (2004). An exploratory study of SME management in the Middle East. International Journal of Entrepreneurship and Small Business, 1(1-2), 121-135. doi:10.1504/IJESB.2004.005380.

Whysall, P., Foster, C., \& Harris, L. (2009). Job dissatisfaction among retail employees: a study of three leading UK retailers. The International Review of Retail, Distribution and Consumer Research, 19(2), 179-198. doi:10.1080/09593960903109519.

Wood, P. A., \& Walther, J. H. (2000). The future of academic libraries: Changing formats and changing delivery. The Bottom Line, 13(4), 173-182. doi:10.1108/08880450010355904.

Wotruba, T. R. (1990). The relationship of job image, performance, and job satisfaction to inactivity-proneness of direct salespeople. Journal of the Academy of Marketing Science, 18(2), 113-121. doi:10.1177/009207039001800202.

Zehery, M. H. (1975). Libraries and librarianship in kuwait. International Library Review, 7(1), 3-13. doi:10.1016/0020-7837(75)90016-3.

Zehery, M. H. (1997). University library development in the Arab Gulf region: A survey and analysis of six state university libraries. International Information and Library

Review, 29(1), 13-44. doi:10.1006/iilr.1997.0030. 